Kumawula, Vol. 1, No.1, April 2018, Hal 16 - 30 DOI:http://10.24198/kumawula.v1i1.18778

ISSN 2620-844X (online)

Tersedia online di http://jurnal.unpad.ac.id/kumawula/index

\title{
"SOLIDARITAS TANPA BATAS IDENTITAS" LOMBA PENULISAN CERITA PENDEK BAGI SISWA SEKOLAH MENENGAH ATAS DI JATINANGOR DAN KABUPATEN BANDUNG
}

\author{
Taufik Hidayat $^{*}$, Deasy Silvya Sari ${ }^{2}$, Siti Aliyuna Pratisti ${ }^{3}$ \\ ${ }^{1,2,3}$ Departemen Hubungan Internasional, Fakultas Ilmu Sosial dan Ilmu Politik \\ taufik.hidayat@unpad.ac.id¹, deasy.silvya@unpad.ac.id², siti.aliyuna@unpad.ac.id³
}

\begin{abstract}
ABSTRAK
Artikel ini membahas mengenai wujud solidaritas menentang kekerasan etnis dalam bentuk lomba penulisan cerita pendek bagi Siswa Menengah Atas di Jatinangor dan Bandung. Tujuan dari artikel ini adalah untuk menggugah rasa empati masyarakat terhadap kekerasan yang berlangsung, khususnya yang menimpa etnis Rohingya yang membuat etnis tersebut harus bermigrasi dari Myanmar ke beberapa negara, seperti: Bangladesh, Thailand, Malaysia, dan Indonesia. Metode yang digunakan adalah partisipasif dalam bentuk lomba cerpen dan sosialisasi. Hasil kegiatan menunjukkan antusiasme dan solidaritas untuk menentang kekerasan telah ditunjukkan oleh masyarakat Indonesia, khususnya para siswa SMA. Format PPM dalam bentuk lomba penulisan cerita pendek diapresiasi sangat baik oleh pihak sekolah, khususnya guru Bahasa Indonesia, karena mampu memotivasi mahasiswa agar mau berkarya dan kreatif. Kesimpulan menunjukkan bahwa masyarakat Indonesia memiliki solidaritas dan empati terhadap kekerasan yang terjadi pada etnis Rohingya. Solidaritas ini terlihat dari naskah-naskah cerpen yang ikut serta dalam lomba yang diselenggarakan dalam skema pengabdian pada masyarakat yang terintegrasi dengan KKN.
\end{abstract}

Kata Kunci: Kekerasan terhadap Kelompok Etnis, Solidaritas, Lomba Penulisan Cerita Pendek

\section{“SOLIDARITY BEYOND THE LIMIT OF IDENTITY” WRITING CONTEST FOR HIGH SCHOOL STUDENTS IN JATINANGOR AND THE REGENCY OF BANDUNG}

\begin{abstract}
This article explores the response and solidarity of high school students in Jatinangor and the Regency of Bandung toward ethnic violence captured in short story writing contest. The purpose of this article is to raise the empathy of toward the tragedy, especially toward Rohingya that has experienced such atrocities which lead to fled outside the country to neighbour states, like Bangladesh, Thailand, Malaysia, and Indonesia. The article uses participation and socialisation methods in the form of the writing contest. The result shows that the high school students are enthusiastic about following the news and shows their solidarity in the form of a short story. Students and teachers, especially the Bahasa Indonesia teacher, give a proper appreciation for this writing contest as a method that can motivate the student to produce some manuscripts creatively. The result shows that Indonesian have solidarity and
\end{abstract}


empathy toward Rohingya. Solidarity beyond the limit of identity as depicted in the short story manuscript that participates in the contest.

Keywords: Violence toward Ethnic Group, Solidarity, Short Story Writing Contest

\section{PENDAHULUAN}

Konflik Rohingya di Myanmar telah menjadi perhatian internasional terlebih ketika gelombang pengungsi menandatangi berbagai negara untuk mendapatkan perlindungan. Penanganan konflik ini belum memenukan titip terang karena sikap pemerintah Myanmar yang cenderung mengabaikan konflik, dan terdapat indikasi kekerasan struktural karena pemerintah Myanmar sendiri tidak mengakui keberadaan etnis Rohingya sebagai bagian dari bangun kewarganegaraan Myanmar. Identitas, khususnya identitas reliji, menjadi salah satu faktor yang mendorong terjadinya kekerasan struktural ini - penduduk Myanmar, dan Rakhine khususnya, merupakan penganut Budha, sedangkan etnis Rohingya memeluk agama Islam. Dalam sebuah konflik etnis, identitas senantiasa menjadi konstruksi utama terjadinya diskriminasi dan represi, dan seringkali menjadi pembenaran atas tindakan yang dilakukan atas kelompok identitas lain. Faktor identitas dalam sebuah konflik juga sering menjadikan konflik tersebut meluas keluar batas teritori negara. Kasus Rohingya pun demikian mengalami perluasan serupa, yaitu dengan munculnya dukungan dari komunitas Islam transnasional yang digerakkan atas kesamaan identitas. Sehingga penelitian ini mencoba menggali bentuk dan pola solidaritas yang digalang oleh komunitas islam transnasional terhadap pengungsi Rohingya di Indonesia.

Konflik antara masyarakat mayoritas di Rakhine (yaitu negara bagian dimana etnis Rohingya bermukim) dengan masyarakat minoritas Rohingya bukanlah hal yang baru, karena kebijakan diskriminatif terhadap etnis Rohingya telah diberlakukan oleh Inggris melalui pemisahan wilayah Rakhine yang memisahkan antara pemukiman etnis Buddha Myanmar dan pemukiman Muslim Rohingya. Namun bentuk dikriminasi terhadap etnis Rohingya semakin mencolok ketika junta Myanmar menyatakan bahwa tidak ada yang disebut sebagai kelompok etnis minoritas Rohingya dalam sejarah Myanmar, sedangkan minoritas lain mendapat pengakuan. Dibawah junta militer Myanmar, melalui Burma Citizenship Law (BCL) tahun 1982 muncul kebijakan baru dimana warga Rohingya tidak mendapat kewarganegaraan, hak atas tanah, dan pendidikan serta pekerjaan yang layak dan cukup (Chan, 2006). Diskriminasi ini memuncak ketika masyarakat Rakhine ditengarai melakukan kekerasan terhadap etnis Rohingya dan menyebabkan banyak masyarakat Rohingya yang mengungsi untuk mendapatkan perlindungan di berbagai negara, termasuk Indonesia. 
Bentuk diskriminasi ini bertentangan dengan hakikat negara untuk melindungi setiap warga negaranya sebagaimana tercantum dalam Deklarasi Universal Hak Asasi Manusia 1948 PBB Pasal 15. Selain bersinggungan dengan pelanggaran tanggung jawab negara terhadap setiap warganya, kasus konflik etnis Rohingya juga bersinggungan dengan masalah identitas yang menjadi konstruksi konflik utama. Myanmar yang mayoritas beragama Budha dipandang melakukan diskriminasi terhadap minoritas muslim Rohingya. Kerangka identitas ini memunculkan peta baru dalam konflik Rohingya di Myanmar melalui solidaritas transnasional yang disuarakan oleh masyarakat muslim. Indonesia yang merupakan salah satu negara dengan mayoritas muslim adalah salah satu contoh bagaimana solidaritas tersebut hadir dalam bentuk yang cukup signifikan. Melalui berbagai bentuk aksi protes yang ditujukan pada perwakilan Myanmar di Indonesia, solidaritas penggalangan dana, hingga penyaluran bantuan secara langsung kepada korban dan pengungsi Rohingya, masyarakat muslim di Indonesia bersamasama menyuarakan bentuk keprihatinannya pada konflik Rohingya.

Bentuk solidaritas yang bersandingan dengan konflik identitas bukanlah sebuah hal baru dalam konteks hubungan internasional. Sejarah telah merekam bagaimana solidaritas muslim terhadap kemerdekaan Palestina, atau solidaritas pasca kemerdekaan negara-negara di AsiaAfrika yang mendasari gerakan Non-blok. Namun, perkembangan globalisasi informasi saat ini menjadikan solidaritas transnasional semakin mengemuka. Melalui kemudahan berbagi informasi, permasalahan etnis Rohingya tidak lagi hanya menjadi isu domestik di Myanmar, tapi juga menjadi permasalahan dunia. Perhatian masyarakat global terhadap isu Rohingya muncul dalam dimensi yang lebih kuat khususnya pada masyarakat muslim. Kuatnya solidaritas ini muncul atas dasar persinggungan identitas - dengan kata lain, identitas islamlah yang menjadi penggerak utama bagi keterlibatan komunitas islam dalam penanganan korban dan pengungsi Rohingya. Identitas memunculkan “rasa kolektif”, yaitu sebuah konstruksi yang mengacu pada rasa kepemilikan seorang individu atas kelompok (ingroup) yang dalam pembentukannya dapat didorong oleh berbagai fenomena didalam atau dengan kelompok lain (Luhtanen and Crocker 1992: 25). Dalam kasus kekerasan terhadap Rohingya, etnis yang menjadi korban beragama Islam, sehingga muncullah gelombang simpati dari masyarakat muslim lain yang didasari atas rasa emosional kesamaan identitas.

Dalam kasus kemanusiaan di Rohingya Indonesia juga turut aktif melakukan upaya guna penyelesaian sengketa di negara tersebut. Melihat respon masyarakat di Indonesia, memang tidak dapat dipungkiri ada sebagian oknum yang memanfaatkan momen ini dengan hal-hal yang berkaitan dengan identitas. Namun, baik orang-orang yang memiliki kesamaan identitas dengan 
korban maupun kesamaan identitas dengan pelaku, mereka secara bersama-sama menentang keras peristiwa kemanusian di Rohingya tersebut.

Kemudian, wujud solidaritas masyarakat Indonesia terhadap isu-isu yang berlangsung di dalam negeri, dapat terlihat bahwasannya solidaritas antara golongan masih kental terasa. Contohnya, dalam tragedi Sinabung. Sinabung termasuk kedalam wilayah Kabupaten Karo yangmana mayoritas penduduknya beragama Kristen. Tetapi, di saat terjadi letusan gunung Sinabung, berbagai lapisan masyarakat dari berbagai identitas yang berbeda, baik suku, agama, ras, maupun identitas yang lain, berduyun-duyun membantu, menunjukan simpati dan empati, serta melakukan aksi solidaritas untuk membantu para penduduk Sinabung. Hal ini memperlihatkan bahwasannya masyarakat Indonesia telah memiliki sikap solidaritas antar sesama tanpa memandang batas identitas.

Beberapa contoh wujud solidaritas yang dipaparkan di atas, terlihat bahwa masyarakat Indonesia telah memiliki solidaritas terhadap orang maupun golongan, baik itu yang berada di luar wilayah Indonesia maupun di dalam wilayah Indonesia itu sendiri. Dapat ditarik kesimpulan bahwa masyarakat Indonesia, pada dasarnya, tidak mempedulikan identitas yang dimiliki seseorang, mereka menunjukan solidaritasnya terhadap siapapun yang membutuhkan tanpa memandang identitas orang yang membutuhkan tersebut. Agama, ras, suku, ataupun identitas lainnya, tidaklah menjadi suatu hambatan bagi masyarakat Indonesia untuk membantu satu sama lain.

Berdasarkan keadan-keadaan tersebut, Tim KKN PPM Terintegrasi Unpad 2018 memandang bahwa keadaan di Indonesia adalah keadaan yang ideal: sebuah keadaan yang memang seharusnya terjadi sesama umat manusia. Namun, belakangan ini di Indonesia, sering terjadi suatu upaya dari oknum-oknum tertentu untuk melakukan politisasi terhadap identitas dan berusaha untuk melakukan indoktrinasi kepada masyarakat bahwasannya identitas merupakan suatu hal yang sakral. Akibatnya, masyarakat akan menjadi terpecah, masyarakat akan menganggap golongannya yang terbaik, dan lama-kelamaan solidaritas yang telah dipraktikan oleh masyarakat dan Bangsa Indonesia pun perlahan-lahan memudar dan lenyap.

Melihat kondisi Indonesia sekarang yang menjunjung tinggi solidaritas tanpa batas identitas serta adanya tantangan bagi Indonesia berupa upaya oknum-oknum tertentu yang mencoba untuk mendapatkan kekuasaan dan lain sebagainya dengan menggunakan identitas serta melakukan politik identitas, maka kegiatan PPM dan KKN Terintegrasi yang bertemakan “SOLIDARITAS TANPA BATAS IDENTITAS” merupakan suatu hal yang mendesak untuk dilakukan. Guna menyampaikan pemahaman soldaritas tanpa identitas khususnya dalam 
isu-isu kemanusiaan, tanpa dengan cara yang menggurui, Tim KKN-PPM Terintegrasi Unpad 2018 berupaya mewujudkannya dalam bentuk Lomba Penulisan Cerpen dengan sasaran kalangan remaja, dengan lingkup SMA di Jatinangor dan Kabupaten Bandung. Program ini diharapkan dapat menjadi suatu ajang untuk menumbuhkan kesadaran di dalam diri remaja bahwasannya Indonesia merupakan negara yang senantiasa mempraktikan sikap solider tanpa memandang identitas. Selain itu, kegiatan ini juga dapat dimanfaatkan sebagai suatu sarana untuk memberikan gambaran kepada kalangan remaja tentang bahaya laten dari penyalahgunaan identitas dan politik identitas, sehingga kedepannya akan tercetak remaja yang tidak menganggap identitas sebagai hal yang perlu disakralkan serta remaja yang mampu untuk menunjukan solidaritasnya kepada sesama tanpa memandang identitas satu sama lain. Pada akhirnya, yang ingin dicapai dari adanya program ini adalah masyarakat dan Bangsa Indonesia yang tetap solid dan tidak terkotak-kotakan dalam kelompok-kelompok tertentu.

Tujuan diselenggarakannya PPM adalah menanamkan nilai-nilai solidaritas tanpa batas identitas, khususnya, dalam merespon isu-isu kemanusiaan dengan metode yang sederhana dan dapat dilakukan oleh masyarakat, terlebih dengan sasaran remaja yang tentunya memerlukan sebuah metode yang lebih kreatif, seperti halnya dalam format Lomba Penulisan Cerita Pendek (Cerpen). Hasil dari kegiatan ini diharapkan mampu memberikan manfaat bagi TIM PPM dan sasaran dari kegiatan PPM ini, meliputi:

- Harapan bagi masyarakat, khususnya remaja dapat menumbuhkan dan menjaga solidaritas dan kepedulian terhadap sesama

- Menumbuhkan simpati dan empati di dalam diri masyarakat, khususnya remaja akan peristiwa-peristiwa kemanusian yang terjadi tanpa melihat identitas dari mereka yang mengalami peristiwa tersebut

- Menumbuhkan pemahaman masyarakat, khususnya remaja, jika identitas tidaklah menjadi batasan dan/atau penghalang dari solidaritas antara sesama manusia

- Menimbulkan kepekaan kepada remaja akan isu-isu serta permasalahan-permasalahan yang sedang terjadi

- Mencetak remaja-remaja yang tetap solider dan peduli terhadap sesama tanpa didasari oleh identitas

- Mengajak remaja untuk tidak terpengaruh dengan penyalahgunaan identitas dan politisasi identitas yang dilakukan oknum-oknum tertentu

- Mengajak remaja untuk senantiasa terus mempraktikan solidaritas terhadap sesama umat manusia yang tidak mengenal batasan identitas 


\section{METODE}

Metode yang dipergunakan dalam kegiatan PPM ini adalah kegiatan lomba dan sosialisasi. Metode lomba ditujukan agar tercipta partisipasi aktif dari sasaran PPM berupa berbagi (sharing) pengetahuan, ide, dan rasa mengenai kasus-kasus kemanusiaan, salah satunya apa yang terjadi dengan pengungsi Rohingya di Indonesia. Metode sosialisasi dilaksanakan di SMAN Rancaekek pada saat kegiatan pembagian raport. Dalam kegiatan ini, Tim PPM diberi waktu oleh pihak sekolah untuk menyampaikan tujuan dan manfaat kegiatan PPM serta pembagian hadiah bagi siswa yang memenangkan lomba cerpen ini. Dalam pelaksanaannya, tim PPM dibantu oleh tim KKN mahasiswa dalam kerangka kegiatan PPM terintegrasi KKN. Alur kegiatan PPM ini adalah sebagai berikut:

\section{Gambar 1. Alur Kegiatan PPM}

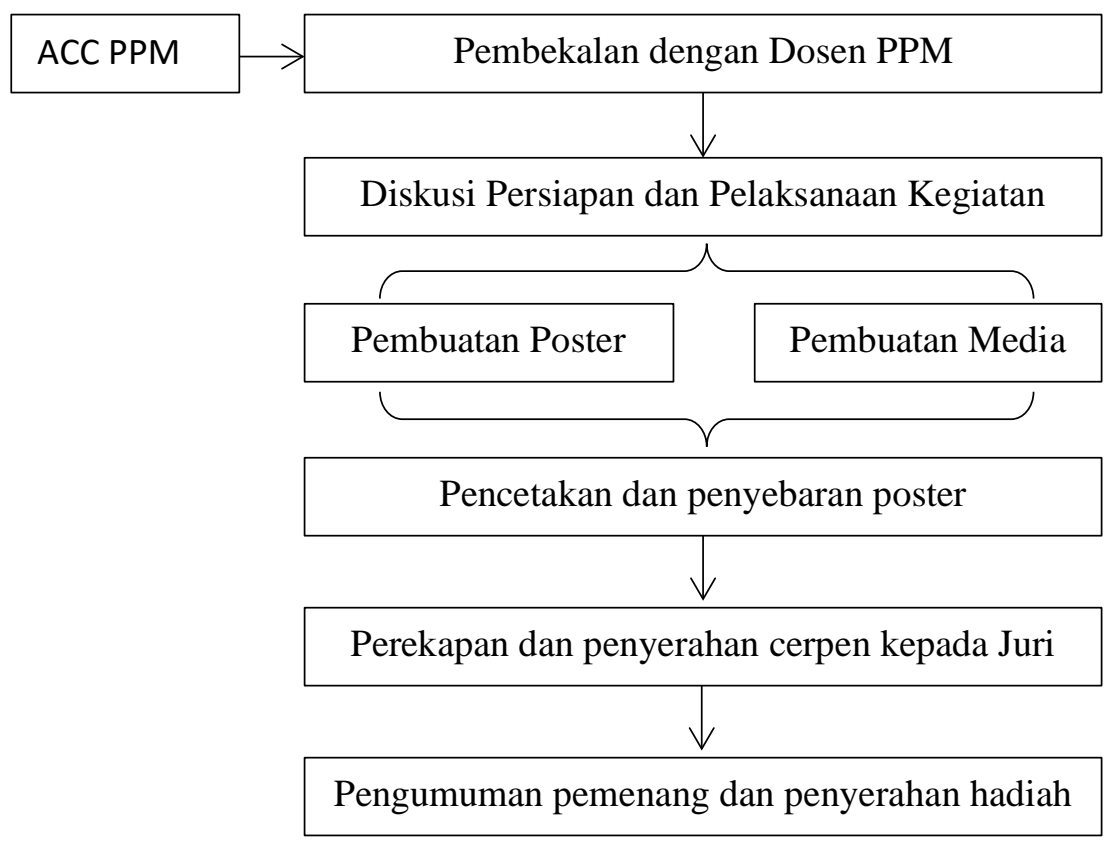

Sumber: Tim PPM-KKN. 2018 


\section{HASIL DAN PEMBAHASAN}

\section{Hasil}

PPM UNPAD periode 2018 dengan tema ‘Solidaritas Tanpa Batas Identitas’ ini terdiri dari tiga orang tim dosen dan sepuluh orang mahasiswa dari berbagai Fakultas, meliputi Fakultas Hukum, Fakultas Ekonomi, Fakultas Ekonomi, Fakultas Ilmu Sosial dan Ilmu Politik, Fakultas Ilmu Budaya, Fakultad Kedokteran, Fakultas Psikologi, dan Fakultas Komunikasi. PPM dengan tema 'Solidaritas Tanpa Batas Identitas', ditujukan pada masyarakat yang berada dalam tahap remaja (dalam hal ini berada pada rentang umur 12-18 tahun).

Dalam perlombaan cerpen ini, peserta dituntut untuk membuat sebuah cerpen sesuai dengan tema tersebut, seperti isu-isu kemanusiaan dengan metode yang sederhana dan dapat dilakukan oleh masyarakat, pentingnya solidaritas dan kepedulian akan sesama di dalam masyarakat, baik solidaritas dan kepedulian di dalam masyarakat Indonesia maupun masyarakat internasional, serta menyadarkan masyarakat, khususnya remaja, akan bahaya penggunaan identitas sebagai sarana untuk mencapai suatu tujuan-tujuan yang negatif (Vestergaard, 2011).

Berikut ini adalah beberapa jenis aktivitas yang dilakukan oleh tim PPM Unpad dalam upaya memberikan pemahaman tentang solidaritas tanpa batas identitas pada kalangan siswa SMA di Jatinangor. Susunan kegiatan sesuai dengan metode yang telah ditetapkan, yaitu meliputi:

\section{Diskusi}

Pada aktivitas ini, dilakukan perbincangan di dalam tim PPM Unpad terkait dengan beberapa hal penting, meliputi: jadwal diskusi per minggunya, baik daring maupun secara langsung, spesifikasi karakteristik pihak masyarakat yang akan dituju, berbagai administrasi dan perizinan yang diperlukan selama berjalannya KKN, serta penyusunan konten dan perencanaan kegiatan yang akan dilaksanakan nantinya.

\section{Pembuatan Poster dan Media Sosial}

Pada aktivitas ini, dilakukan pembuatan poster, disesuaikan dengan hasil diskusi mengenai aturan perlombaan, desain bentuk dan warna, serta konten-konten apa saja yang akan dicantumkan di dalam poster. Terkait dengan media sosial, juga dilakukan pembuatan akun, yaitu akun media sosial Instagram sebagai sumber informasi dan membantu penyebaran poster, dan official e-mail sebagai media pengedaran poster secara soft file ke sekolah-sekolah di Jatinangor.

3. Pencetakan dan Penyebaran Poster 
Pada aktivitas ini, dilakukan pencetakan dari desain poster yang sudah dibuat sebelumnya. Kemudian, setiap poster yang sudah dicetak langsung disebarkan ke sekolah-sekolah yang berada pada cakupan wilayah sasaran. Penyebaran poster juga tidak hanya dilakukan dengan mendatangi sekolah secara langsung, tetapi juga melalui pengiriman softfile ke setiap e-mail sekolah yang tidak terjangkau dikarenakan jarak yang cukup berjauhan.

4. Penyerahan Cerpen Kepada Juri

Pada aktivitas ini, setelah batas pengumpulan karya berakhir (yaitu 30 Juni 2018), maka tim PPM Unpad merekap setiap karya yang sudah diterima ke dalam satu folder, dan langsung dikirimkan ke pada pihak dosen PPM untuk dinilai oleh juri perlombaan.

5. Rapat Akhir Kegiatan KKN disertai dengan Pengumuman Pemenang Lomba

Pada aktivitas ini, setelah karya setiap peserta dinilai oleh juri, diadakan pertemuan terakhir secara langsung yang dihadiri oleh tim KKNM dan dosen PPM. Hal-hal yang dibahas terkait dengan pengumuman pemenang perlombaan, halal bi halal antar tim KKNM-PPM, serta imbauan dan pemaparan sistematika laporan akhir yang akan disusun oleh tim KKNM.

6. Penyerahan Hadiah

Pada aktivitas ini, sebagian tim KKNM dan dosen PPM secara langsung ikut turun ke dalam beberapa sekolah, mengumumkan pemenang, serta memberikan hadiah secara langsung kepada pemenang perlombaan.

7. Penulisan Laporan dan Evaluasi

Pada aktivitas ini, tim KKNM melakukan penyusunan laporan berdasarkan berbagai aktivitas yang sudah dilakukan sebelumnya. Juga, selama penyusunan, tim dosen PPM tetap melakukan pengawasan dan apabila perlu memberikan feedback terkait konten dan sistematika laporan.

8. Presentasi

Pada aktivitas ini, tim PPM Unpad melakukan pemaparan hasil laporan yang telah disusun terkait dengan beragam kegiatan yang sudah dilakukan selama masa PPM berjalan, disesuaikan dengan waktu pertemuan dengan dosen DPL terkait.

Adapun cakupan wilayah dalam pelaksanaan KKNM ini yaitu pada Kecamatan Jatinangor dan Sekitarnya, meliputi daerah-daerah yang dijelaskan dalam daftar tabel berikut:

No $\quad$ Nama Kota/Kabupaten/Kecamatan/Kelurahan/Desa 


\begin{tabular}{|l|l|}
\hline 1 & Kecamatan Jatinangor \\
\hline 2 & Desa Cibeusi \\
\hline 3 & Desa Sayang \\
\hline 4 & Desa Cisaladah \\
\hline 5 & Desa Cikeruh \\
\hline 6 & Kecamatan Rancaekek \\
\hline
\end{tabular}

KKNM-PPM UNPAD periode 2018 dengan tema 'Solidaritas Tanpa Batas Identitas’ ini terdiri dari sepuluh Mahasiswa dari berbagai Fakultas, meliputi Fakultas Hukum, Fakultas Ekonomi, Fakultas Ekonomi, Fakultas Ilmu Sosial dan Ilmu Politik, Fakultas Ilmu Budaya, Fakultad Kedokteran, Fakultas Psikologi, dan Fakultas Komunikasi. Kegiatan yang dilaksanakan oleh tim KKNM yaitu mengadakan lomba cerpen dengan tema 'Solidaritas Tanpa Batas Identitas', ditujukan pada masyarakat yang berada dalam tahap remaja (dalam hal ini berada pada rentang umur 12-18 tahun).

Dalam perlombaan cerpen ini, peserta dituntut untuk membuat sebuah cerpen sesuai dengan tema tersebut, seperti isu-isu kemanusiaan dengan metode yang sederhana dan dapat dilakukan oleh masyarakat, pentingnya solidaritas dan kepedulian akan sesama di dalam masyarakat, baik solidaritas dan kepedulian di dalam masyarakat Indonesia maupun masyarakat internasional, serta menyadarkan masyarakat, khususnya remaja, akan bahaya penggunaan identitas sebagai sarana untuk mencapai suatu tujuan-tujuan yang negatif.

Tujuan dari PPM ini yaitu agar mahasiswa dapat mengabdi dan belajar dari masyarakat tentang kehidupan bermasyarakat yang sesungguhnya, khususnya isu yang berkaitan dengan kemanusiaan, serta mengajak masyarakat untuk menunjukan rasa solidaritas dalam menanggapi isu-isu tersebut tanpa melihat identitas. Juga, bagi tim PPM Dosen, bertujuan untuk menanamkan nilai-nilai solidaritas tanpa batas identitas khususnya dalam merespon isu kemanusiaan dengan metode yang sederhana dan dapat dilakukan oleh masyarakat, pentingnya solidaritas dan kepedulian akan sesama di dalam masyarakat, baik solidaritas dan kepedulian di dalam masyarakat Indonesia maupun masyarakat internasional, serta menyadarkan masyarakat. Kemudian, bagi masyarakat, bertujuan untuk menyadarkan masyarakat, khususnya remaja di wilayah Bandung, Jatinangor, dan sekitarnya, akan pentingnya solidaritas dan kepedulian terhadap sesama di dalam masyarakat, baik solidaritas di dalam masyarakat indonesia maupun masyarakat internasional. 
Adapun tahapan dalam melakukan kegiatan PPM terintegrasi dengan KKN ini adalah sebagai berikut:

Tabel 1. Tahapan kegiatan PPM Terintegrasi KKN

\begin{tabular}{|c|c|c|c|c|c|}
\hline No & Kegiatan & Waktu & Tempat & $\begin{array}{l}\text { Pelaksana dan } \\
\text { Sasaran }\end{array}$ & $\begin{array}{c}\text { Hasil (Capaian } \\
\text { Target) }\end{array}$ \\
\hline 1 & Penerimaan PKM & 26 Maret 2018 & & $\begin{array}{l}\text { Dosen Pembimbing } \\
\text { Lapangan (DPL) }\end{array}$ & \\
\hline 2 & $\begin{array}{l}\text { Pembekalan PKM } \\
\text { dengan mahasiswa } \\
\text { KKN }\end{array}$ & 9 April 2018 & $\begin{array}{l}\text { Kampus Unpad } \\
\text { Jatinangor }\end{array}$ & $\begin{array}{l}\text { Dosen dan } \\
\text { Mahasiswa KKN }\end{array}$ & $\begin{array}{l}\text { Pemaparan mengenai } \\
\text { kegiatan KKN }\end{array}$ \\
\hline 3 & $\begin{array}{l}\text { Rapat perdana } \\
\text { peserta KKN }\end{array}$ & 16 April 2018 & $\begin{array}{l}\text { Che.co Café } \\
\text { Jatinangor }\end{array}$ & Mahasiswa & Pembagian tugas KKN \\
\hline 4 & Diskusi & 17 April 2018 & Jatinangor & Mahasiswa & $\begin{array}{l}\text { Penentuan tema dam } \\
\text { format pasti penulisan } \\
\text { Cerita Pendek }\end{array}$ \\
\hline 5 & Pembuatan Poster & 22 April 2018 & Jatinangor & Mahasiswa & $\begin{array}{l}\text { Poster sosialisasi } \\
\text { lomba }\end{array}$ \\
\hline 6 & $\begin{array}{l}\text { Pembuatan Media } \\
\text { Sosial }\end{array}$ & 24 April 2018 & Secara daring & Mahasiswa & $\begin{array}{l}\text { Dibuatnya Media } \\
\text { Sosial sebagai sarana } \\
\text { promosi lomba }\end{array}$ \\
\hline 7 & Pencetakan Poster & 2 Mei 2018 & $\begin{array}{l}\text { Copa Digital } \\
\text { Printing }\end{array}$ & Mahasiswa & $\begin{array}{l}\text { Dibuatnya Poster } \\
\text { sebagai sarana } \\
\text { promosi lomba }\end{array}$ \\
\hline 8 & Penyebaran Poster & 3-6 Mei 2018 & $\begin{array}{l}\text { Sekolah } \\
\text { Menengah di } \\
\text { sekitar } \\
\text { Jatinangor }\end{array}$ & Mahsiswa & $\begin{array}{l}\text { Tersebarnya Poster di } \\
\text { Sekolah Menengah di } \\
\text { sekitar Jatinangor }\end{array}$ \\
\hline 9 & $\begin{array}{l}\text { Penyerahan Cerpen } \\
\text { kepada Juri }\end{array}$ & 30 Mei 2018 & Secara daring & $\begin{array}{l}\text { DPL dan } \\
\text { Mahasiswa }\end{array}$ & $\begin{array}{l}\text { Penyerahan Cerpen } \\
\text { untuk dinilai oleh Juri }\end{array}$ \\
\hline 10 & $\begin{array}{l}\text { Rapat Akhir } \\
\text { Kegiatan KKN }\end{array}$ & 4 Juni 2018 & $\begin{array}{l}\text { Gigglebox Café } \\
\text { Jatinangor }\end{array}$ & $\begin{array}{l}\text { DPL dan } \\
\text { Mahasiswa }\end{array}$ & $\begin{array}{l}\text { Pembahasan dan } \\
\text { laporan terakhir } \\
\text { kegiatan KKN }\end{array}$ \\
\hline 11 & $\begin{array}{l}\text { Pengumuman } \\
\text { Pemenang Lomba }\end{array}$ & 6 Juni 2018 & Secara daring & $\begin{array}{l}\text { DPL dan } \\
\text { Mahasiswa }\end{array}$ & $\begin{array}{l}\text { Penentuan pemenang } \\
\text { lomba Cerpen }\end{array}$ \\
\hline 12 & $\begin{array}{l}\text { Penyerahan Hadiah } \\
\text { kepada Pemenang }\end{array}$ & 9 Juni 2018 & $\begin{array}{l}\text { Sekolah } \\
\text { Menengah di } \\
\text { sekitar } \\
\text { Jatinangor }\end{array}$ & $\begin{array}{l}\text { DPL dan } \\
\text { Mahasiswa kepada } \\
\text { Peserta Lomba }\end{array}$ & $\begin{array}{l}\text { Apresiasi terhadap } \\
\text { peserta lomba yang } \\
\text { berhasil menjadi } \\
\text { pemenang }\end{array}$ \\
\hline
\end{tabular}

\section{Sumber: Tim PPM-KKN, 2018}

\section{Pembahasan}

Rasa toleransi di Indonesia, kini kerap diwarnai oleh aksi fanatisme yang berakar pada identitas tertentu. Melihat fenomena, hal tersebut telah menunjukan bahwa identitas acap kali digunakan oleh pihak-pihak yang tidak bertanggung jawab untuk memecah belah masyarakat. Ujaran kebencian, yang bertujuan untuk menghasut dan menyulut kebencian terhadap individu dan/atau kelompok masyarakat dalam berbagai komunitas yang dibedakan dari aspek :

- Suku 
- Agama

- Aliran keagaman

- Keyakinan/kepercayaan

- Ras

- Antar golongan

- Warna kulit

- Etnis

- Gender

- Kaum difabel; dan

- Orientasi sexual

Penggunaan narasi identitas dengan tidak bertanggung jawab dapat mengakibatkan masyarakat awam semakin jauh dari rasa toleransi dan sikap solidaritas. Lebih lanjut, dampak dari identitas adalah timbulnya suatu anggapan akan eksklusivitas suatu golongan yang mana polanya hampir mirip dengan pola yang dihadirkan fasisme, dimana akan muncul anggapan dari golongan yang merasa eklusif, paling hebat, paling benar tersebut bahwasannya golongan diluar mereka, yang identitasnya berbeda, adalah suatu bentuk kesalahan yang tidak bisa ditolerir. Mengingat bahaya yang dihadirkan oleh adanya identitas tersebut, maka tim PPM Terintegrasi Unpad 2018 memandang perlunya menciptakan suatu sikap yang tidak mensakralkan terkait identitas guna merawat toleransi dan solidaritas yang terbangun di dalam masyarakat. Adanya solidaritas yang tidak mengenal identitas, tentunya, akan menimbulkan suatu bentuk kerukunan yang dapat menghadirkan harmonisasi antara golongan-golongan yang ada di dalam suatu masyarakat, baik masyarakat Indonesia maupun masyarakat Internasional. Selanjutnya, pola tingkah laku yang cenderung mendukung solidaritas akan menimbulkan kepekaan masyarakat terhadap suatu isu maupun permasalahan-permasalahan yang terjadi, khususnya permasalahan kemanusiaan, baik yang terjadi di internal maupun eksternal suatu masyarakat.Dalam pelaksanaan kegiatan PPM, setiap tim memiliki peran tersendiri. Dosen memiliki peran dalam hal ideasi kegiatan, baik itu dalam bentuk tema dan format kegiatan. Adapun dalam pelaksanaan kegiatan, kolaborasi dosen dan mahasiswa KKN sangat penting. Mahasiswa dapat memberikan dan berbagi pengalaman tentang penggunaan dan pencarian berita melalui media sosial. Selain itu, mahasiswa juga dapat memahami isu identitas yang muncul di masyarakat, bahkan ketika akar permasalahan tidak secara langsung terdapat di Indonesia. Kesenjangan usia antara dosen dengan sasaran KKN dapat disinergikan oleh 
mahasiswa KKN. Misalnya, gagasan promosi kegiatan yang lebih diintensifkan melalui media sosial seperti instagram dan facebook sangat efektif dan efisien bagi generasi milenial. Dalam hal yang sama, tim dosen masih memikirkan kunjungan secara langsung ke sekolah-sekolah. Bagusnya, kolaborasi ide ini dilaksanakan secara bersamaan, sehingga terdapat penghematan yang cukup besar dari biaya promosi kegiatan.

Adapun tujuan dari PPM akan secara spesifik membahas tentang peran komunitas transnasional, termasuk pelajar didalamnya, untuk ikut berperan secara langsung dalam menyebarkan solidartitas kemanusian. Fokus lain yang menjadi kajian PPM ini adalah membedah keterkaitan faktor identitas dalam komunitas internasional yang dikemukakan oleh Milani dan Laniado (2007), bahwa setiap gerakan sosial transnasional senantiasa didorong oleh kesamaan identitas. Penegasan identitas dalam gerakan transnasional bukan hanya mengacu pada realisasi gagasan politik saja, namun juga atas isu universal terkait permasalahan global. Indikasi kehadiran elemen identitas dalam gerakan transnasional tersebut tercermin dalam unsur simbolik (seperti agama, ras, jenis kelamin, bangsa, hingga kelompok minoritas). Identitas inilah yang menjadi dasar konstruksi yang menggerakan individu untuk memberikan kontribusinya, baik secara formal ataupun secara personal.

Kegiatan PPM yang terintegrasi KKN di akhir kegiatan memberikan perubahan kepada khalayak sasaran. Kegiatan ini mampu menggugah rasa empati, terlebih lagi membuat masyarakat tergerak hatinya untuk mendukung isu-isu kemanusiaan yang berada jauh di luar ruang lingkup mereka, seperti apa yang terjadi pada pengungsi Rohingya merupakan usaha yang tidak mudah. Meski demikian, meninjau upaya yang telah dilakukan oleh tim PPM dan KKN, sasaran dari kegiatan PPM ini terlihat antusiasnya melalui naskah cerpen. Pada saat kegiatan kunjungan ke SMAN Rancaekek untuk memberikan hadiah yang bertepatan dengan acara pembagian raport, wali kelas dan guru bahasa Indonesia terlihat antusias memberikan arahan kepada siswa untuk mengikuti kegiatan-kegiatan positif seperti lomba cerpen ini serta kepada orang tua siswa agar mendukung anak-anak mereka untuk berprestasi. Mereka juga mengapresiasi positif kegiatan PPM yang dilakukan dalam bentuk lomba sebagai sebuah kegiatan yang kreatif dalam melibatkan siswa-siswa untuk mengasah keterampilan menulis dan rasa peduli terhadap sesama. Ucapan terima kasih disampaikan oleh wali kelas dan guru bahasa Indonesia terhadap keberlangsungan kegiatan PPM ini.

Kegiatan dalam PPM-KKN ini didasari oleh fenomena penggalangan aksi bentuk solidaritas yang masih terkotak-kotakkan berdasarkan identitas tertentu. Berangkat dari fenomena tersebut maka dirasa perlu adanya penyuluhan kepada masyarakat khususnya 
generasi muda tentang manfaat serta pentingnya perilaku atau sikap solidaritas dengan tidak melihat perbedaan identitas dari suku, ras, dan agama (SARA) salah satunya sehingga dapat menghindari tindakan diskriminasi antar golongan ataupun tindakan lain yang dapat mengganggu kesatuan sebagai bangsa Indonesia. Mengingat kondisi Indonesia yang memiliki keberagaman tinggi dan nilai toleransi yang tinggi antar golongannya sesuai dengan asas Pancasila serta berkaca pada banyaknya peristiwa baru-baru ini yang seolah memisahkan antar golongan di masyarakat maka kegiatan PPM-KKN ini sangat dibutuhkan terutama bagi generasi muda penerus bangsa agar kesatuan bangsa ini dapat terus dipelihara sampai masa yang akan datang.

\section{SIMPULAN}

Sekolah sebagai lembaga pendidikan formal tidak hanya berfungsi memberikan pelajaran tetapi sekolah juga berpungsi sebagai transmisi sikap, nilai-nilai, dan norma-norma. Penanaman sikap solidaritas amat sangat penting diberikan terhadap siswa agar para siswa mempunyai kecerdasan IQ dan social yang seimbang (balance). Upaya-upaya sekolah dalam membentuk solidaritas siswa dengan membuat program-program kegiatan yang meliputi: (1) Bidang keagamaan; (2) Bidang Sosial; (3) Pembinaan ekstra kurikuler. Upaya-upaya tersebut merupakan sebagian kecil pendidikan solidaritas yang diberikan sekolah terhadap siswa namun pendidikan solidaritas yang paling efektif adalah keteladanan yang istiqamah dari para pendidik.

Dengan upaya-upaya tersebut ternyata dapat memberikan perubahan yang signifikan terhadap siswa. Siswa yang tadinya bersikap cuek dan selalu membuat onar yang dapat meresahkan masyarakat, kini siswa mempunyai kepedulian sosial yang tinggi. Dan jangan lupa untuk selalu mengajak para siswa-siswi untuk berkarya. Melalui sosialisasi terhadap generasi muda dalam program KKNM-PPMD Integratif ini sendiri diharapkan dapat menjadi sebuah harapan bagi masa depan remaja Indonesia atas kesadarannya solidaritas sosial dalam peristiwa kemanusiaan tanpa batas identitas untuk menjadi lebih baik. Dengan adanya upaya untuk meningkatkan kepedulian siswa-siswi di Jawa Barat yang akan baik untuk jangka waktu yang panjang.

Kasus Rohingya merupakan salah satu bentuk kekerasan yang saat ini sedang berlangsung di kawasan Asia Tenggara berupa tindak kekerasan yang mengakibatkan etnis Rohingya melakukan migrasi dari Myanmar ke beberapa negara, seperti: Thailand, Bangladesh, Malaysia, dan Indonesia. Tahun 2017, Tim dosen melakukan penelitian mengenai etnis 
Rohingya yang masuk dan sempat tinggal di Aceh selama beberapa waktu. Empati terhadap kehidupan mereka, baik sebagai pengungsi maupun sebagai etnis yang mengalami tindak kekerasan di negara asalnya. Mewacanakan berlangsungnya kekerasan terhadap etnis Rohingya dengan identitas muslimnya, merupakan hal yang menantang: antara mudah dan sulit. Mudah karena sebagian penduduk Indonesia memiliki kesamaan identitas yakni sebagai muslim. Sulit karena wujud empati yang dapat disuguhkan oleh masyarakat Indonesia terhadap Rohingya harus dilakukan dalam bentuk apa? Donasi dana tidak semua masyarakat Indonesia mampu melakukannya, meski donasi dana pun memang telah berlangsung. Tim peneliti berupaya mewacanakan kekerasan kepada masyarakat dengan sasaran pemuda sebagai upaya untuk menggugah kepedulian dan empati mereka terhadap kekerasan yang menimpa etnis Rohingya. Upaya ini dilakukan dalam bentuk lomba penulisan cerita pendek. Diintegrasikan dengan program KKN Mahasiswa, PPM ini menyelenggarakan lomba penulisan cerita pendek dengan sasaran siswa-siswa SMA di daerah Jawa Barat dengan sarana promosi melalui kunjungan langsung dan media sosial.

\section{UCAPAN TERIMAKASIH}

Terima kasih tim PPM sampaikan kepada Rektor Universitas Padjadjaran Prof. Dr. Med. Tri Hanggono Achmad, dr atas skema riset Hibah Internal Unpad yang mendukung riset dan PPM yang dilaksanakan dalam semester genap 2018.

\section{DAFTAR PUSTAKA}

Chan, Aye. (2005). "The Development of a Muslim Enclave in Arakan (Rakhine) State of Burma (Myanmar)", SOAS hal. 398. Diunduh 17 Januari 2017.

Galtung, Johan, 1958, Theories of Conflict: Definition, Dimension, Negation and Formation, Columbia University Press, New York

Luhtanen, R. dan J. Crocker, 1992, “A collective self-esteem scale: Self-evaluation of one's social identity”, dalam Personality and Social Psychology Bulletin, 18, 302-318

Milani, C. R. S. dan Laniado, R. N., 2007, “Transnational social movements and the globalization agenda: a methodological approach based on the analysis of the world social forum”, dalam Brazilian Political Science Review, 1(2), 10-39

Ross, 2007, Cultural Contestation in Ethnic Conflict, Cambridge University Press, New York Soekanto, Soerjono, 1993, Sosiologi Makro, Rajawali, Jakarta 
Vestergaard, Bjarne; Helvard, Erik \& Sorensen, Aase Rieck. 2011. Conflict resolution: Working with Conflicts. Denmark: Danish Center for Conflict Resolution.

Zeitlin, Irving M., 1998, Memahami Kembali Sosiologi, Kritik terhadap Teori Sosiologi Kontemporer, alih bahasa Anshori dan Juhanda, Gajah Mada Press, Yogyakarta 